\title{
A Comparison of Malaysian Ethnic and Political Stand-up Comedies' Text Structures and Use of Politeness Strategies
}

Chan Teik Onn, Helen Tan*, Ain Nadzimah Abdullah, Chan Swee Heng

Faculty of Modern Languages and Communication Universiti Putra Malaysia, Serdang 43400, Selangor, Malaysia

Corresponding Author: Helen Tan, E-mail: helen@upm.edu.my

\section{ARTICLE INFO}

Article history

Received: July 15, 2018

Accepted: October 02, 2018

Published: December 01, 2018

Volume: 7 Issue: 7

Advance access: October 2018

Special Issue on Language \&

Literature

Conflicts of interest: None

Funding: None

\begin{abstract}
This paper attempts to investigate and compare the text structures of ethnic and political Malaysian stand-up comedies and their use of politeness strategies to mitigate backlash. To this end, a mixed method approach was adopted where the structural properties were tabulated to determine the dominant structural patterns of the stand-up comedies. Additionally, a content analysis was used to examine the different politeness strategies used in both types of stand-up comedies. A sample of 17 ethnic jokes and 13 political jokes were analyzed using Hockett's (1960) Internal Structure of Jokes and Brown and Levinson's (1987) Politeness Strategies as frameworks of analyses. Results on the textual structures showed that although the two types of comedies employed the standard three part structures which are build-up, pivot and punch line. Build-ups were used more in ethnic jokes than political jokes. This could be due to the nature of ethnic stand-up comedy where comedians need to specify a target stereotype to prevent generalization. In terms of politeness strategies used off record strategy was the dominant strategy in both types of jokes, although political jokes over-relied on this strategy, which is $32.33 \%$ in ethnic jokes and $56.66 \%$ in political jokes. It was also found that ethnic jokes, had a more diverse use of politeness strategies due to its different payoffs such as to mitigate backlash by showing hesitation with discourse markers and using word choices that showed a partial understanding to the aspects of a race that they were making fun of, unlike political jokes, which focused on ambiguity so as not to directly name the political figure in their jokes. In short, findings from this paper may serve as a valuable resource for not only aspiring comedians but also public speakers in presenting social criticism without risking backlash.
\end{abstract}

Key words: Stand-Up Comedy, Ethnic Jokes, Political Jokes, Joke Structure, Politeness Strategies, Backlash

\section{INTRODUCTION}

Van Dijk (2002) states that discourse is a communicative function that includes both written and oral aspects of communication. The risks carried by spoken discourse are arguably higher, because according to Sinclair et al. (1992) things that are spoken cannot be erased or amended such as in written form. This case is also true for stand-up comedy discourse. Stand-up comedy performances carry the same risks, as they are in spoken form, with the difference that such discourse mostly focuses on eliciting laughter.

There is a need to set a distinctive line between stand-up comedy and conversational humour so that the results yielded by this study are dissociated from jokes found in everyday conversations. The differences in the characteristics between stand-up comedy and conversational humour are as follow. Attardo and Chabanne (1992:172) claim that stand-up comedy does not encourage feedback from the audience. In conversational humour, jokes often come spontaneously and are traded back and forth between the speaker and the hearer, which is different from stand-up comedy due to its scripted delivery. Therefore, they conclude that stand-up comedy is different from conversational humour due to the fact that the former often comes with a planned program in mind, eliminating the need for the audience to offer any replies. In addition, they also state that any form of communication by the audience during a stand-up comedy performance can be seen as a form of disruption, whereas in conversational humour, replies and feedback are often encouraged. Sacks (1992) also added that conversational humour often requires transition in order for the speaker to begin joking. In conversational humour, a phrase such as 'I remember a joke' is often needed by the speaker to be detached from the conversation whereas in stand-up comedy, such transition is not needed. Because of the context of the performance, in which the audience knows that the sole reason for the comedian to be present is to tell jokes, comedians are expected to be- 
gin their performance without any form of transition. Even though stand-up comedies seem to lack transitional boundaries they are nevertheless not without structures.

To discuss deeper into the discourse of stand-up comedy, which will be referred to as 'jokes' in this paper, Attardo (2001:62) suggests that although stand-up comedy may appear to be spontaneous talks, it is in fact a meticulously scripted discourse. Jokes performed during a stand-up comedy performance often went through a brainstorming process similar to speeches. This means that the narrative structure and strategies undertaken to mitigate backlash are often considered during the process. Such characteristic of jokes has since led to multiple studies that are focused on investigating its structural use and rhetorical strategies.

For instance, Hockett (1960) has laid out a benchmark for the structure of jokes known as the Internal Structure of Jokes, where he suggested that a joke typically contains a build-up, a pivot and a punch line. This structure allows jokes to flow coherently. Build-up, as proposed by Hockett (1960), allows the comedian to lay out sufficient background information to set up the joke. Pivot, on the other hand, sets up a sense of misunderstanding or disconnect which detaches the joke from the build-up provided, and punch line exploits such misunderstanding to a humorous degree. The lack of build-up may signify the lack of background information, which is a risk carried by comedians because according to Forceville (2005), the key for a joke to be successful is the background information that the audience have towards specific topics discussed by the comedian. Therefore, in order to present a joke successfully without build-up, comedians must have solid grasp on what topics are well-known among the audience.

This discovery became a catalyst for several studies on joke structures. Selma (2014) conducted a study to investigate how the structure of jokes can be used to ensure the effectiveness of humour in Indonesian comedy TV shows. In this study, she classified parts of transcribed jokes into three categories: build-up, pivot and punch line in order to determine if the omission of any stages would cause the humour to be less effective. She found no discernible link between the effectiveness of a joke and any violation related to the joke structures. Additionally, it was discovered that there is a significant number of comedians who forgo the use of build-ups in their jokes. Unfortunately, no explanation was given as to why build-ups were excluded in some of the jokes. Pivot and punch line, however, remained in use in all of the jokes.

In another related study, Attardo and Pickering (2011) set out to establish a link between intonation and the use of the joke structure. They hypothesize that comedians have a lower speech rate before delivering the punch line in order to maximize the impact of the punch line. To study this phenomenon, they compared the speech rates between the performances of comedians and people doing interviews. As a result, they discovered that stand-up comedy has a lower speech rate than people doing interviews. Stand-up comedy yielded a speech rate of 3.43 syllables per second whereas interviews yielded a speech rate of 4.31 syllables per second. However, when the speech rate of stand-up comedy was compared across the three stages of the Internal Structure of Jokes, Attardo and Pickering (2011) observed no significant differences. This means that the speech rate was constant throughout the entire joke and did not fluctuate when it reached the punch line as they had hypothesized. They concluded the study by stating that the effectiveness of punch lines in stand-up comedy is not affected by speech rates.

However, it is not sufficient to focus solely on the structural properties of jokes. Toikka and Vento (2000) have observed that jokes typically contain crude criticisms hidden by cleverly scripted wordplays. The instance where a comedian is observed to be teasing or making fun of the audience or another party is not an isolated case.Such occurrences call for the use of politeness strategies, as coined by Brown and Levinson (1987), in order for comedians to keep inflammatory remarks at bay. Politeness strategies, as defined by Brown and Levinson (1987), are made up of four distinctive strategies known as bald on-record, off record, positive politeness and negative politeness in order to mitigate face threat. Bald on-record is often presented without any redressive actions and is regarded as the most direct form of communication. It is more focused on getting the point across without concerning the face threat made. Off record, on the other hand, is face threat presented in an ambiguous manner, where the speaker tries to be as less direct as possible. This strategy is often used when the speaker wishes to give the hearer the credit of being the one to figure the meaning out and take initiative. Positive politeness is more grounded on appealing to the hearers' face, which includes the acts of praising and offering understanding and sympathy in order for the speaker to appear to be agreeable. Negative politeness, however, focuses on minimizing imposition so that the speaker will not appear to be crossing the boundaries related to the hearers' negative face. It is often presented in an apologetic and self-effacing manner.

On studies related to politeness strategies in stand-up comedies, Katayama's (2009) study was noted to have examined on how politeness strategies were used among two different groups of comedians: American and Japanese in order to see how these characteristics may differ. It was found that Japanese comedians are more likely to exclude their audiences from the performance through the use of negative politeness, whereas American comedians tend to use positive politeness to interact directly with their audience. It was also found that the use of politeness strategy across these two groups of comedians was due to the differences in the format of the performances. Japanese stand-up comedy was presented in manzai format, in which there were two comedians standing on the stage making fun of one another. American stand-up comedy, however, had only one comedian standing on the stage interacting with the audience. From this observation, Katayama (2009) concluded that Japanese comedians tended to minimize imposition by directing face threats towards one another while American comedians tended to interact directly with the audience, using positive politeness in order to show understanding. Therefore, the differences in the use of politeness strategies were attributed to the format of the performances.

There is a need to make a clear distinction between ethnic and political jokes. Ethnic jokes as defined by Jakoaho et al. 
(2012) mostly deal with jokes that contain stereotypes on a certain ethnicity. Stereotypes, as explained by McGarty et al. (2002), are group beliefs about a certain ethnicity and are energy-saving tools that help the audience make sense of a situation regarding an ethnicity. Mindiola (2002) also adds that stereotypes can generate a positive or negative effect on an ethnicity, as opposed to the belief that stereotypes are often derogatory in nature. Political jokes, however, are defined by Wilson (2008) to contain topics that revolve around governmental practices and political figures. Political jokes often come in trivialized form, according to Gadavanij (2002), so that it could relate to audience's everyday life.

Interestingly, the issue of ethnicity and politics is often discussed in Malaysia despite its strict censorship laws. Malaysian stand-up comedy is no stranger to such phenomenon. According to Azizudin (2007), the media is largely suppressed by the Malaysian government in order for them to retain their influence, which comes in the form of a censorship law, which also affects the development of stand-up comedy performances in Malaysia. Failure to comply with the strict laws of censorship may cause comedians to be persecuted for making defamatory remarks. Although studies on jokes have been documented in several studies in the past and mostly on jokes delivered in western society, there is a dearth of studies pertaining to Malaysian comedies and how comedians circumvent existing laws in delivering their social criticism. Furthermore, without a proper study that dissects on how jokes are structured, aspiring comedians may be hard pressed to produce a joke that is comprehensible and coherent.

The paucity on studies pertaining to Malaysian stand-up comedy particularly the investigation of the text structure and politeness strategies has motivated this paper to examine the extent the text structure and politeness strategies used in Malaysian ethnic stand-up comedies are different from the political stand-up comedies. In this regard, the following research questions were framed to guide the study.

1. How is the text structure of Malaysian ethnic stand-up comedies different from Malaysian political stand-up comedies?

2. To what extent are the politeness strategies employed in the Malaysian ethnic stand-up comedies different from the Malaysian political stand-up comedies?

\section{METHODOLOGY}

A mixed method approach was adopted where the structural properties were tabulated to determine the dominant structural patterns of the stand-up comedies based on Hockett's (1960) Internal Structure of Jokes as the framework of analysis. A content analysis was also done on the gathered tran- scribed jokes to examine the extent the politeness strategies were employed. To this end, Brown and Levinson's model on politeness strategies was adopted.

\section{Data Collection}

30 jokes performed by various Malaysian comedians were selected via purposive sampling. This set of data was mainly promotional videos uploaded on public domain such as YouTube and other social media. The 30 jokes were screened for content on social criticism. Jokes that did not contain this element were discarded because they were not aligned to the objective of this study.

After the jokes were obtained, they were separated into two categories according to their content: Ethnic and political jokes according to their meaning and content. Ethnic jokes are classified as jokes that make fun of an ethnic stereotype, which includes race and religion, whereas political jokes are classified as jokes that make fun of political policies, governments, and figures. Based on this criterion of selection, a total of 17 ethnic jokes and 13 political jokes were selected as sample of this study.

\section{Analysis Procedure}

In analyzing the jokes, the researcher had to read thoroughly each joke and identify the boundaries that set off the different stages of jokes structures as defined by Hockett (1960). They are build-up, pivot and punch line. Once that was done, the frequency of occurrences of the three stages in both the ethnic and political joke structures was tabulated and compared.

In order to illustrate how these structures are classified, an example by Schwarz (2010) is given:

After waiting for half an hour in a Soho restaurant the customer called over to the waiter: "How long will my spaghetti be?" he asked. "How should I know?" replied the waiter. "I never measure it."

In this joke, the build-up can be identified through the phrase "After waiting for half an hour in a Soho restaurant...". This is because the opening line provides the context of the joke which uses Soho restaurant as the setting of the joke. Next, the pivot is represented by the question asked by the customer, 'How long will my spaghetti be?'. Note that this phrase is the point where the misunderstanding occurs. The waiter assumes that the question is about length of the spaghetti rather than time it will take to prepare the dish, which leads to the punch line, 'I never measure it.' The punch line makes use of the previous misunderstanding, labeled as the pivot, and in turn generates a humorous conclusion. A summary of the three distinct stages of jokes is found in Table 1.

Table 1. Hockett's (1960) internal structure of jokes

\begin{tabular}{ll}
\hline Stages & Description \\
\hline Build-up & Sets up background information \\
Pivot & A line or a sentence that introduces incongruity \\
Punch line & $\begin{array}{l}\text { Exploits the incongruity given in the previous stage to provide a 'twist' to the narration, which includes a humorous } \\
\text { conclusion }\end{array}$ \\
\hline
\end{tabular}


After the analysis of the internal structure of jokes, the content of the sample was examined closely for the use of politeness strategies. As mentioned in the Introduction, politeness strategies are made up of four distinctive strategies: bald on-record, off record, positive politeness and negative politeness. Examples of the usage of each strategy are shown in Table 2 along with their characteristics.

In ensuring that this study is both reliable and valid, two raters were employed to counter check the analysis of joke structures and politeness strategies used by the standup comedians. Discrepancies in the analyses were resolved through a consensus between the researcher and the raters. The outcome of the exercise was the adoption of Hockett's (1960) Internal Structure of Jokes and Brown and Levinson's (1989) Politeness Strategies as frameworks of the study (see below for details).

\section{FINDINGS AND DISCUSSION}

In this section, findings and discussion pertaining to the internal structure of jokes and the use of politeness strategies of jokes are provided along with tabulated data and examples.

\section{Comparison of the Text Structure of Ethnic and Political Jokes}

Table 3 demonstrates the occurrences of build-up, pivot and punch line in the ethnic and political stand-up comedies.

As shown in Table 3, only a marginal number (5.88\%) of ethnic jokes were found to be delivered with no buildup. This is consistent with Schwarz's (2010) claim that one of the main functions of build-ups is to make a joke seem specific, and in order to pinpoint the main topic for comedians to deliver it comprehensively. In these jokes that dealt with racial stereotypes, comedians used build-ups in order to specify a stereotype so that they can avoid overgeneralizing.

As illustrated in the example below, a comedian attempted to make fun of Malaysian Chinese people's lack of table manners. A build-up stage is included to buffer the face threat.

\section{"Malaysian Etiquette"}

This is one thing about Malaysian people, we have customs - we have customs or etiquette or adab - adab adat and adab or kastam dan etiket, whichever one you wanna say - we all have it. Malay people have it, Indian people have it, (Build-up)

Chinese people... They - let's not say anything about Chinese people - they're fine. They're just trying to be efficient. (Pivot)

They got no time for table manners, you know what I mean? (Punch line)

As demonstrated above, the build-up stage details the topic that the comedian was about to discuss, which was about table manners. The face threat, which was directed at the Chinese people, was presented gradually, where he went from the general topic of etiquettes in the build-up to Chinese people trying to be efficient in the pivot stage. The face threat only appeared at the punch line, where the comedian hesitantly stated that Chinese people had no time for table manners. The build-up allowed the comedian to lead the target of the joke towards the face threat by specifying the topic through the stages.

However, there were also ethnic jokes in the gathered data that forgo the use of build-ups although they were scarce. The joke below demonstrates that when certain information

Table 2. Brown and levinson's (1987) politeness strategies

\begin{tabular}{|c|c|c|}
\hline Politeness strategies & Description & Examples \\
\hline Bald on-record & Made with no redressive actions, direct utterance & $\begin{array}{l}\text { I am proud at my country, Malaysia, we have an } \\
\text { astronaut. And I am extra proud because... Singapore } \\
\text { don't have. }\end{array}$ \\
\hline Off record & $\begin{array}{l}\text { Give hints, give association clues, understate, use } \\
\text { metaphors, be rhetorical }\end{array}$ & $\begin{array}{l}\text { All of you Chinese here today, you are in a much more } \\
\text { better position than most of the MCA politicians. You } \\
\text { know why? At least you all got seats. }\end{array}$ \\
\hline Positive politeness & $\begin{array}{l}\text { Claim common ground, be optimistic, show sympathy } \\
\text { towards the target of the joke, use in-group identity } \\
\text { marker such as 'we' or 'us' }\end{array}$ & $\begin{array}{l}\text { You know, I went to India and it was a brilliant - it was } \\
\text { a brilliant show, I love Indian people, but I got stopped } \\
\text { for speeding in your country. }\end{array}$ \\
\hline Negative politeness & $\begin{array}{l}\text { Frame utterances as questions in order to show } \\
\text { hesitation, apologize, violate own face, minimize } \\
\text { imposition }\end{array}$ & $\begin{array}{l}\text { Okay, I know there're a few Singaporeans here ah, } \\
\text { never mind, this is just a joke ah okay? }\end{array}$ \\
\hline
\end{tabular}

Table 3. Occurrences of hockett's (1960) internal structure of jokes in ethnic and political jokes

\begin{tabular}{|c|c|c|c|c|}
\hline \multirow{2}{*}{$\begin{array}{l}\text { Types of jokes } \\
\text { Jokes structures }\end{array}$} & \multicolumn{2}{|c|}{ Ethnic } & \multicolumn{2}{|c|}{ Political } \\
\hline & No of jokes $N=17$ & Percentage & No of jokes $N=13$ & Percentage \\
\hline Build-up & 16 & 94.11 & 8 & 61.54 \\
\hline Pivot & 17 & 100 & 13 & 100 \\
\hline Punch line & 17 & 100 & 13 & 100 \\
\hline
\end{tabular}


is well-known enough, it is possible for the comedian to skip the build-up stage entirely.

\section{"Malaysian Pride"}

I'm proud to be Malaysian. I just - I just, those of you don't know, do you know why Malaysians are proud to be Malaysians? (Pivot)

Cause we're not Singaporeans. (Punch line)

The comedian was aware of the fact that there had been a long rivalry between Malaysia and its neighbor Singapore. Therefore, the comedian had the opportunity to shorten the joke by omitting the build-up stage. Instead, he began his joke with the pivot, asking the question why Malaysians are proud to be Malaysians before answering with his punch line, because [they're] not Singaporeans.

In contrast, comedians who delivered political jokes were less likely to utilize build-ups than those who delivered ethnic jokes. Compared to ethnic jokes, which only had 5.88\% jokes that omitted the build-up stage, there were $38.46 \%$ of political jokes that omitted the build-up stage. Political jokes that did not use build-up were often less specific in nature, which was similar to ethnic jokes. Nevertheless, there were also occurrences where a build-up was used in order to obscure the true topic until the punch line, which is shown below.

\section{"Roleplaying"}

You know, the thing is my dad - my dad in his infinite wisdom decided to give me some advice, he said, "What you need to do to spice things up is you must role play you must pretend to be someone else." Apparently, I've known my wife for ten years - I've known my wife for ten years and apparently, it's a good idea for me to walk through the door and say, "Hello, I'm the policeman." (Build-up)

She knows who I am, right, but I tried it - I tried it, you know, I - I walked up to her and said, "Eh, bawa laju eh?" (Pivot)

She gave me fifty dollars and left. (Punch line)

The comedian began his joke with a build-up, setting up the audience to a joke that seemingly discussed about relationship and sex, where the comedian attempted to spice things up with his wife. However, in the pivot, he acted upon his father's advice by dressing up as a policeman in the hopes of improving his sex life. In the punch line, the true target of the joke was revealed to be the police force in Malaysia, where he stated that his wife gave him 50 dollars when he 'apprehended' her for driving fast (bawa laju eh?). The punch line was a vague criticism on the rampant bribery that happens in the Malaysian police force.

There were also instances in the data where the comedian omitted the build-up in order to make the joke seem ambig- uous so as not to specify the target of the joke, where the target was often a powerful political figure.

\section{"Short, Fat and Ugly"}

I have to face the fact that I'm cacat, I'm old, short, fat, ugly. So - actually, short, fat, ugly, is not so bad what? (Pivot)

At least I could still marry a prime minister. (Punch line)

The comedian began by dealing face threats on himself, calling himself old, short, fat and ugly, which served as the pivot for the next sentence, where he likened himself to the prime minister's wife. In this joke, the comedian refrained from setting up the identity of the target of the joke so as not to hurt the sentiment of a powerful political figure, and kept it ambiguous by not giving names.

To summarize, among the three stages of the internal structures of jokes, the comedians had only the liberty to omit the build-up stage and it was done on pragmatic grounds. For example, political jokes had less build-ups compared to ethnic jokes. This was to ensure that the censorship law pertaining to defamatory remarks against the government may be circumvented. Therefore, in political jokes, comedians refrained from naming any political figures and giving background information that pinpointed to a certain political event, whereas ethnic jokes benefited greatly from background information in order to set up the joke and the stereotype being made fun of in the joke.

\section{Politeness Strategies in Stand-Up Comedy}

Table 4 illustrates the frequency of use of the four types of politeness strategies in both the Malaysian ethnic and political stand-up comedies. (see Table 4).

The data revealed that off record strategy was dominant in both types of jokes (ethnic jokes $=32.2 \%$; political jokes $=56.66 \%$ ). However, political jokes displayed more reliance on this strategy than ethnic jokes. Ethnic jokes, on the other hand, seemed to be more diverse in terms of its usage of politeness strategies, with its percentage of the most-often used politeness strategy (off-record) at only $32.3 \%$, compared to political jokes' $56.66 \%$ in the same politeness strategy, which was more than half of the total usage of all politeness strategies. This result reinforces the characteristics shown in the payoff intended by the use of internal structure of jokes in ethnic and political jokes. Political jokes, which were previously established to omit the build-up stage more often than ethnic jokes, employed more off record strategy to keep the message of their jokes ambiguous so as not to offend any political parties. On the other hand, ethnic jokes used politeness strategies in a diverse way, carrying less

Table 4. Frequency of politeness strategies in ethnic and political jokes

\begin{tabular}{|c|c|c|c|c|}
\hline \multirow[t]{2}{*}{ Politeness strategies } & \multicolumn{2}{|c|}{ Ethnic jokes $(\mathrm{N}=65)$} & \multicolumn{2}{|c|}{ Political jokes $(\mathrm{N}=30)$} \\
\hline & Raw score & Percentage & Raw score & Percentage \\
\hline Bald on record & 15 & 23.1 & 6 & 20 \\
\hline Positive politeness & 12 & 18.5 & 4 & 13.33 \\
\hline Negative politeness & 17 & 26.2 & 3 & 10 \\
\hline Off record & 21 & 32.3 & 17 & 56.66 \\
\hline
\end{tabular}


emphasis on making their jokes ambiguous, which carries a connection to the widespread use of build-up in order to build background information.

The next dominant strategy for ethnic jokes was negative politeness (26.2\%) followed by bald-on record (23.1\%). Among the four politeness strategies, positive politeness recorded the lowest percentage of occurrence (18.5\%). Conversely, in political jokes, the next dominant strategy after off record was bald-on record (20\%) followed by positive politeness $(13.33 \%)$. Interestingly, while ethnic jokes recorded the lowest occurrence of positive politeness, the political jokes recorded the lowest occurrence of negative politeness (10\%) instead. Different from Katayama's (2009) study on American and Japanese stand-up comedy, in which positive politeness was typically used to be inclusive to the audience rather than excluding them, the gathered data in the present study shows Malaysian comedians tend to maintain social distance when they were making fun of the audience. On the other hand, positive politeness was used more often than negative politeness in political jokes due to the lack of political figures in the audience. Instead, comedians chose to establish a common ground with the audience through positive politeness.

A discussion supported by example on the use of each politeness strategy in both ethnic and political jokes is given below:

\section{Bald On-record}

As defined by Brown and Levinson (1987), bald on-record statements are delivered without redressive actions and are meant to be direct, without consideration of the hearers' face wants and needs.

\section{Ethnic joke 1 - "Sterotypes"}

I don't like to talk about stereotypes, I like to talk about facts, you know? Anyone can come up here - stereotypes. We've got some stereotypes. All Indian people come from Klang. That's not true, right? Some of them live in Jalan Gasing, okay?

In this joke, the comedian used the bald on-record and stereotypical phrase All Indian people come from Klang as a topic statement before debunking it with yet another stereotype that they also come from Jalan Gasing. In this case, the comedian took no risk of backlash despite his use of bald on-record phrase to make fun of the Indian stereotype. This was because the comedian stated the face threat as a factual statement he set out to debunk rather than framing it as his own opinion.

\section{Political joke 1 - "Political Rallies in Malaysia"}

First BERSIH rally, 2008, 40,000 Malay fellows with the yellow T-shirt marching together: "Bersih, bersih".

So exciting. Two weeks later - two weeks later what happened? 20,000 Indian fellows with the red T-shirt: "Hindraf, Hindraf, Hindraf". So exciting.

Bald on-record was once again used in order to lay out the hard facts in order to set up a joke. In this joke, the comedian used two instances of bald on-record to state the facts about Malaysian rallies, demonstrated by two phrases 40,000 Malay fellows with the yellow T-shirt marching to- gether and 20,000 Indian fellows with the red T-shirt. These phrases were mainly used to establish facts rather than to provide criticism.

Bald on-record occurred $23.1 \%$ of the time in ethnic jokes and $20 \%$ in political jokes. In ethnic jokes, bald on-record was mostly used as a tool to introduce the audiences to the topic of discussion by stating the situation that the comedian wished to discuss. In political jokes, bald on-record was mostly treated the same way, which was also to introduce the audience to the topic of discussion. In most of the gathered data, bald on-record was not often used as a face threat but rather as a way for the comedians to explain the situation that they were in so that they could joke about it. This is to say that many occurrences of bald on-record strategy happened in the early parts of the joke, which were the build-up and pivot stages.

\section{Positive politeness}

Positive politeness is defined by Brown and Levinson (1987) as a strategy to appeal to the audience by offering understanding, sympathy and praise in order to mitigate face threats.

\section{Ethnic joke 2 - "Malaysian Etiquettes"}

We have customs or etiquette or adab - adab - adat and adab or kastam dan etiket, whichever one you wanna say - we all have it. Malay people have it, Indian people have it, Chinese people... They - let's not say anything about Chinese people- they're fine. They're just trying to be efficient.

In this joke, the comedian prefaced his joke by stating that all Malaysians have etiquettes, before narrowing down the topic to table manners. The face threat in this joke was directed towards the Chinese people, an accusation that they do not have table manners. However, the comedian framed his face threat by offering understanding towards the target of the joke, stating that they are just trying to be efficient.

\section{Political joke 2 - "The Two MACCs"}

I just want to say of how appreciative I am of you all because you have chosen to support the right MACC. We are the MACC that won't leave you hanging. Don't make your own jokes, don't strangle yourself. We do for you.

The phrase how appreciative I am of you all was used by the comedian to state his appreciation towards his audience, while the second half of the phrase to support the right $M A C C$ implied that he was joking about the Malaysian anti-corruption commission (MACC) - which so happened to have the same name as his comedy organization, Malaysian Association of Chinese Comedians (MACC). This is evident from his use of the phrase support the right $M A C C$, with his use of the word right implying that there was another MACC. However, this strategy is peculiar in political jokes. Positive politeness found in political jokes is not directed towards the target of the face threat, but rather to the audience. This is believed to be due to the fact that targets of political jokes - which are mainly political figures, are usually not present during the performance.

Positive politeness was used $18.5 \%$ of the time in ethnic jokes and only $13.33 \%$ in political jokes. This shows the importance of this strategy in directly appealing to the audience 
in order to mitigate the incoming face threats that follow by showing understanding and placing the comedians and audience on common ground. However, political jokes did not often use this strategy because there was no need for comedians to appeal to the recipient of face threats since the political authorities they were making fun of were not present during the performance. Instead, comedians used positive politeness to gain the audiences' support.

\section{Negative politeness}

Negative politeness is defined by Brown and Levinson (1987) as a strategy to maintain social distance through acts of apologizing or self-effacement in order to minimize imposition towards the hearer. Utterances made with negative politeness also generally show the speaker's hesitation and are represented by questions and hedges.

\section{Ethnic joke 3 - "Angry Indonesians"}

And then, after that Indonesians - because they lost, right? They're like so angry - they were so angry. They were livid, you know - they were rioting in Indonesia - like, government was feeling the lives of Malaysians in Indonesia but - but - but are there any Indonesians here? Are there? No, right?

In this joke, the comedian talked about a football match where Malaysian football supporters attempted to sabotage the Indonesian rival team by shining green laser to blind their goalkeeper. Before continuing with the joke, he shows hesitation, asking if there were any Indonesian audience members present through the phrase are there any Indonesians here. The phrase is classified as negative politeness due to the hesitant tone used by the comedian in order to not sound imposing.

\section{Political joke 3 - "Short, Fat and Ugly 2"}

I have to face the fact that I'm cacat, I'm old, short, fat, ugly. So - actually, short, fat, ugly, is not so bad what?

At least I could still marry a prime minister.

Different from the previous example, this joke took no apologetic stance. The comedian instead opted for self-effacement in order to lower the impact of the face threat with the phrase I'm short, fat and ugly, before drawing similarities between him and the prime minister's wife, where the face threat occurred.

Negative politeness scored $26.2 \%$ in ethnic jokes and only $10 \%$ in political jokes, which was recorded to be the least used politeness strategy in political jokes. In ethnic jokes, negative politeness was used for mainly two purposes: to make fun of oneself and to state the face threat as a general rule. This was considered as a form of hesitation. They were also apologies made by comedians to downplay the face threats that they had made towards their audience members either by self-effacement or making the face threats seem impersonal. In political jokes, however, negative politeness mainly occurred as self-effacement. While using negative politeness in political jokes, comedians did not seem concerned with maintaining social distance with the recipient of their face threats, which were the political authorities.

\section{Off-Record}

Off-record strategy is used to deliver face threats in an ambiguous way, which requires the hearer to figure out the meaning independently. It is used by speakers to avoid being responsible for stating the face threat. It is classified by Brown and Levinson (1987) to be an avoidance-based strategy.

Ethnic joke 4 - "You Better Behave"

I'm thinking, last time Malaysians used to say: "You better behave ah? If not the Bangla will catch you". Nowadays the Bangladeshis are telling their children: "You better behave, if not the Malaysians will catch you. And make you sing Negaraku."

The comedian used off-record strategy with the phrase make you sing Negaraku as a twist to an old cautionary tale where Malaysian children were told to behave before they were kidnapped by Bangladeshis. Instead, he claimed that now Bangladeshis would be the ones telling their children to behave before Malaysians forced them to sing the national anthem. That phrase alludes to the incident where Malaysian voters forced people who looked like foreigners to sing the national anthem to prove their nationality during the $13^{\text {th }}$ General Election.

\section{Political joke 4 - "Speeding"}

What happens is the cop comes up to you and I'm gonna do this in English, ladies and gentlemen. The cop comes up to you and he's like uh: "Ah, ah." S - sorry, sorry sir, w - what did I do, what did I do? "Uh, just now, you're - speeding. Speeding. Speeding." Oh I was speeding, I'm so sorry, I'm so sorry. "Yeah, just now you were speeding. Speeding just now, speeding."

In the joke, the comedian lay out his face threat, which was to criticize the police's incompetence, by imitating the police officer who stopped him, constantly repeating the word speeding to imply that the officer was slow and incompetent. This was classified as an off-record strategy due to the lack of explicit statements that accused the police officer as slow or incompetent.

As stated earlier, off record strategy was the most popular strategy in both ethnic jokes and political jokes, which scored $32.33 \%$ and $56.66 \%$ respectively. However, from the analysis of both ethnic and political jokes, off record remained a one-dimensional politeness strategy, where it functioned only to imply face threats. From the discussion of previous politeness strategies, political jokes differed from ethnic jokes in terms of interaction between the comedians and the recipients of the face threats. In ethnic jokes, comedians were concerned with the feelings of audience members, and therefore would use various politeness strategies, including off record strategy, to mitigate the face threats directed towards the audience members. However, in political jokes, comedians did not interact with the recipients of face threats, which were made up of political authorities, in order to mitigate face threats. Instead, comedians resorted to only off record strategies as a way to mitigate face threats towards political authorities.

Although political jokes mainly targeted people or parties that were not present during the performance, efforts to mitigate such face threats did exist. However, comedians that 
delivered political jokes mainly relied on off record strategy to do so, whereas comedians who delivered ethnic jokes employed various other politeness strategies. The widespread use of off record strategy is in line with Brown and Levinson's (1987) findings, which suggest that off record strategy is mostly chosen by the chatters whenever they want to present a face threat without assuming the responsibility of stating it directly. In the setting of stand-up comedy, comedians in this research also mostly used off record strategy for the same purpose, where they avoided making direct accusations towards the target of the joke but rather resorted to implication. This concludes that political jokes heavily relied on off record strategy in order to go around censorship laws. This is confirmed by Azizudin (2007) as censorship laws are often enforced by the Malaysian government as a way for the political leaders to avoid defamation. Ethnic jokes, on the other hand, often relied on comedians seeking reconciliation with the audience members in order to mitigate backlash.

\section{CONCLUSION}

In conclusion, the aims of the study which were to compare the text structure and use of politeness strategies of Malaysian ethnic and political stand-up comedies had yielded interesting results. Ethnic and political jokes in the setting of Malaysian stand-up comedy, in general, are found to be different in terms of structure and intended payoffs in mitigating backlash. In ethnic jokes, comedians strive for clarity in order to avoid generalization whereas in political jokes, ambiguity is often the goal due to the need to circumvent censorship laws, which explains the lack of use of build-up. Also, ethnic jokes are found to be richer than political jokes in terms of opportunity to use different politeness strategies. Political jokes, however, are one-dimensional and solely focused on ensuring ambiguity in jokes due to the lack of interaction between comedians and the targets of jokes, which are made up of powerful political figure that are unlikely to attend the performance.

These findings are in a way a contribution to the body of literature of stand-up comedy since to date no studies have been done on Malaysian stand-up comedies. Interestingly, in spite of the censorship laws that curb public expressions deemed offensive to the authority (this is true prior to the $14^{\text {th }}$ General Election), the number of Malaysian stand-up comedians has increased evidenced in the mushrooming of many comedy studios such as Crackhouse Comedy and the Malaysian Association of Chinese Comedians in the last six to seven years. The findings revealed that Malaysian standup comedians were very aware of the text structure of jokes and their adept employment of appropriate politeness strategies to avoid backlash of their jokes was ingenious.

Although the study has provided some interesting findings, the sample size of the study was quite small. Perhaps, future studies could increase the sample size so that the results can be generalizable. Additionally, other types of jokes such as conversational humour in Malaysian setting could be an interesting variable to investigate. By extension, a comparison between conversational humour and stand-up comedy may yield interesting data too.
In spite of the limitations, the findings of this study have several benefits. First, it highlights the importance of utilizing politeness strategies not only in jokes but also in daily communication. These politeness strategies have been proven to be effective for the execution of successful communication particularly in spoken discourse. Moreover, this study may also benefit the public speaking community as the findings can serve as a reference on how politeness strategies can be employed alongside social criticism.

\section{REFERENCES}

Attardo, S. (2001). Humorous Texts: A Semantic and Pragmatic Analysis. Berlin: Mouton de Gruyter.

Attardo, S. \& Chabanne, J. (1992). Jokes as a Text Type. Humor. 5(1/2). 165-172.

Attardo, S. \& Pickering, L. (2011).Timing in the performance of jokes. Humor. 24(2). 233-250. doi: 10.1515/ HUMR.2011.015

Azizudin, M. (2007). Freedom of Speech and Democracy in Malaysia. Asian Journal of Political Science, 16(1), 85104.doi: 10.1080/02185370801962440

Brown, P. \& Levinson, S. C. (1987). Politeness: Some Universals in Language Usage. Cambridge: The Press Syndicate of the University of Cambridge.

Forceville, C. (2005). Addressing an audience: Time, place, and genre in Peter van Straaten's calendar cartoons. International Journal of Humor Research. 18(3), 247-278.

Gadavanij, S. (2002). "Intertextuality as Discourse Strategy: The Case of No-Confidence Debates in Thailand." Leeds Working Papers in Linguistics and Phonetics 9, 35-55. doi: 10.1.1.490.7238

Golafshani, N. (2003). Understanding Reliability and Validity in Qualitative Research. The Qualitative Report, 8(4), 597-606. Retrieved from http://nsuworks.nova.edu/tqr/ vol8/iss $4 / 6$

Graeme, R. (2004). The linguistic analysis of jokes. London: Routledge.

Hockett, C. F. (1960). Jokes. The View From Language. Athens, Georgia: University of Georgia Press.

Jakoaho, V. \& Marjamäki, S. (2012). "Oh My God, That Nigger Said Gun!”: Use of ethnic humor in modern stand-up comedy (Master's Thesis), University of Jyväskylä, 2012.

Katayama, H. (2009). A Cross Cultural Analysis of Humor in Stand-Up Comedy in the United States and Japan. Docdroid. Retrieved from https://www.docdroid.net/ 196u/katayama-cross-cultural-analysis-2009.pdf

McGarty, C. Yzerbyt. V. \&R. Spears. (2002). Stereotypes as explanations: the formation of meaningful beliefs about social groups. London; New York: Cambridge University Press.

Mindiola, T. Flores, Y. \& N. Rodriguez. (2002). Blackbrown relations and stereotypes. Austin: University of Texas Press.

Sacks, H. (1992). Lectures on Conversation. Oxford: Black-well.

Selma, K. (2014). Examining Labov's Model and Related Frameworks in Stand-Up Comedy Delivering Jokes 
and Stories. Academia. Retrieved from http://www. Van Dijk, T. (1996). Discourse, power and access. Discoursacademia.edu/8486423/examining_Labovs_model_in_ stand_up_comedy es. Retrieved from http://www.discourses.org/OldArticles/Discourse, $\% 20$ power\%20and\%20access.pdf

Sinclair et al. (1992). Advances in Spoken Discourse Analy- Walsh, W.B. (1995). Tests and Assessment. New York: Prensis. London: Routledge. tice-Hall.

Toikka, M. \& Vento, M. (2000). Ala Naurattaa! Stand Up - Wilson, C. P. (1979). Jokes: Form, Content, Use and Funckomedian käsikirja. Cosmoprint: Helsinki. tion. Academic Press. 